\title{
Double left brachiocephalic vein in an adult patient who underwent cardiac surgery: a case report
}

\author{
Kimihiro Kobayashi* ${ }^{*}$, Tetsuro Uchida, Yoshinori Kuroda, Atushi Yamashita, Eiichi Ohba, Shingo Nakai, \\ Tomonori Ochiai and Mitsuaki Sadahiro
}

\begin{abstract}
Background: A double left brachiocephalic vein is an extremely rare venous anomaly.

Case presentation: Herein, we present the case of a 79-year-old woman with a double left brachiocephalic vein who underwent cardiac surgical procedures. The normal left brachiocephalic vein was patent, and the accessory left brachiocephalic vein passed across the heart and aorta in front of the pericardium and drained into the superior vena cava. She underwent surgical ligation of the accessory left brachiocephalic vein, followed by an aortic valve replacement and coronary artery bypass grafting. Her postoperative recovery was uneventful, without any venous complications from the ligation of the accessory vein. The patient is doing well one year after the surgery.

Conclusions: The presence of double left brachiocephalic veins should be recognized before cardiac surgery in order for us to avoid intraoperative technical issues concerning this venous anomaly and unpredictable intraoperative bleeding due to injury of the accessory left brachiocephalic vein.
\end{abstract}

Keywords: Vascular anomaly, Left brachiocephalic vein, Cardiac surgery, Case report

\section{Background}

A double left brachiocephalic vein $(\mathrm{BCV})$ is a rare vascular anomaly, and only a few cases have been reported [1]. In addition to the normal left $\mathrm{BCV}$, the accessory left $\mathrm{BCV}$ passes various courses, such as the retroaortic, preaortic, retrotracheal, and retroesophageal, and drains into the superior vena cava $[1,2]$. Herein, we present the case of a patient with an accessory left BCV passing a preaortic course, who underwent cardiac surgical procedures.
*Correspondence: ki-kobayashi@med.id.yamagata-u.ac.jp Second Department of Surgery, Faculty of Medicine, Yamagata University, 2-2-2 lida-Nishi, Yamagata 990-9585, Japan

\section{Case presentation}

A 79-year-old woman with severe aortic valve stenosis and coronary artery disease was scheduled for cardiac surgery. Preoperative contrast-enhanced computed tomography $(\mathrm{CT})$ incidentally revealed a double left $\mathrm{BCV}$ (Fig. 1). The left subclavian vein and left internal jugular vein merged to form the left $\mathrm{BCV}$, which then divided into two branches: the normal and accessory left BCVs. The accessory left BCV was tortuous and passed across the front of the ascending aorta. Both the left BCVs drained into the superior vena cava at a level higher than the azygos vein. Following a median sternotomy, anterior mediastinal tissue was carefully dissected and the accessory left $\mathrm{BCV}$ was easily identified. The left accessory $\mathrm{BCV}$ passed across the heart and ascending aorta in front of the pericardium and drained into the superior vena cava at the same level as the normal left $\mathrm{BCV}$ (Fig. 2). Prior to opening the pericardium, the accessory original author(s) and the source, provide a link to the Creative Commons licence, and indicate if changes were made. The images or other third party material in this article are included in the article's Creative Commons licence, unless indicated otherwise in a credit line to the material. If material is not included in the article's Creative Commons licence and your intended use is not permitted by statutory regulation or exceeds the permitted use, you will need to obtain permission directly from the copyright holder. To view a copy of this licence, visit http://creativecommons.org/licenses/by/4.0/. The Creative Commons Public Domain Dedication waiver (http://creativecommons.org/publicdomain/zero/1.0/) applies to the data made available in this article, unless otherwise stated in a credit line to the data. 


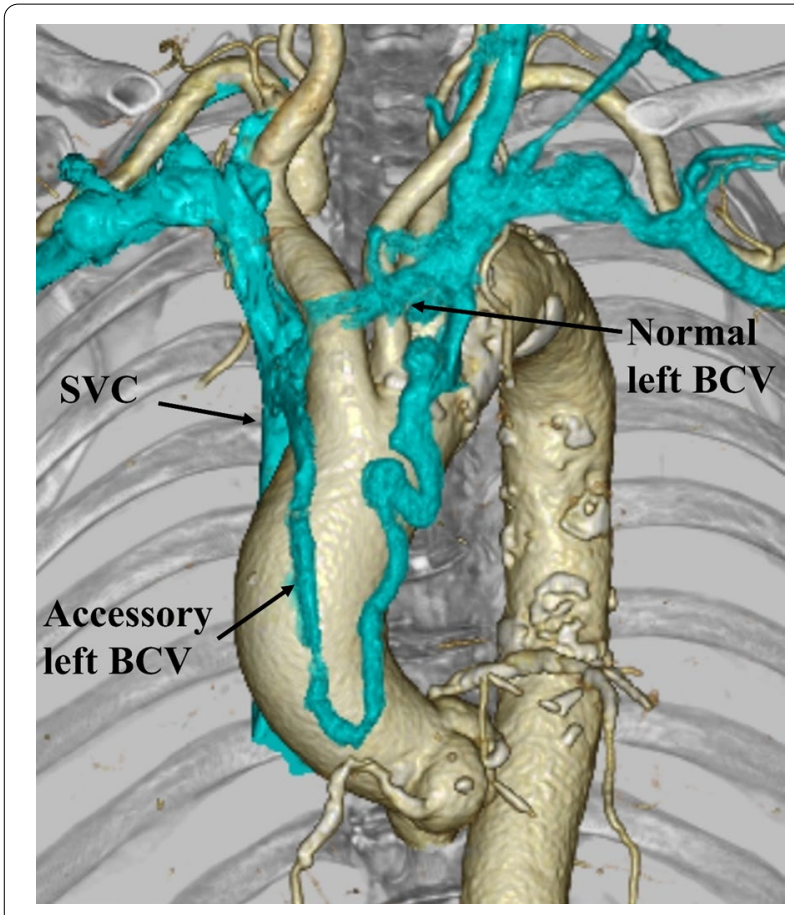

Fig. 1 The 3D-reconstructed image of the double left brachiocephalic vein. BCV, brachiocephalic vein; SVC, superior vena cava left BCV was surgically ligated and divided (Fig. 3), because the normal left BCV was patent. Subsequently, an aortic valve replacement and coronary artery bypass grafting to the left anterior descending artery using the left internal mammary artery was performed. The postoperative course was uneventful, without any complications from the ligation of the accessory left $\mathrm{BCV}$, such as upper body congestion. Histopathological examination of the resected wall of the accessory left $\mathrm{BCV}$ showed normal structures.

\section{Discussion and conclusions}

A double left BCV was first described by Subirana in 1986 [3]. Since then, there have been few additional reports of this venous anomaly. Due to its rarity, the incidence and developmental mechanisms are not well understood [1]. The normal left $\mathrm{BCV}$ originates in the transverse channel formed between the precardinal veins during the 4th to 8 th week of fetal development $[1,2,4]$. Some authors have speculated that double transverse channels and their remnants might lead to the formation of a double left BCV $[1,2]$.

Clinically, most double left $\mathrm{BCVs}$, by themselves, do not affect the patient's condition. However, when performing the insertion of central venous catheters and electrical leads through the left subclavian vein, there
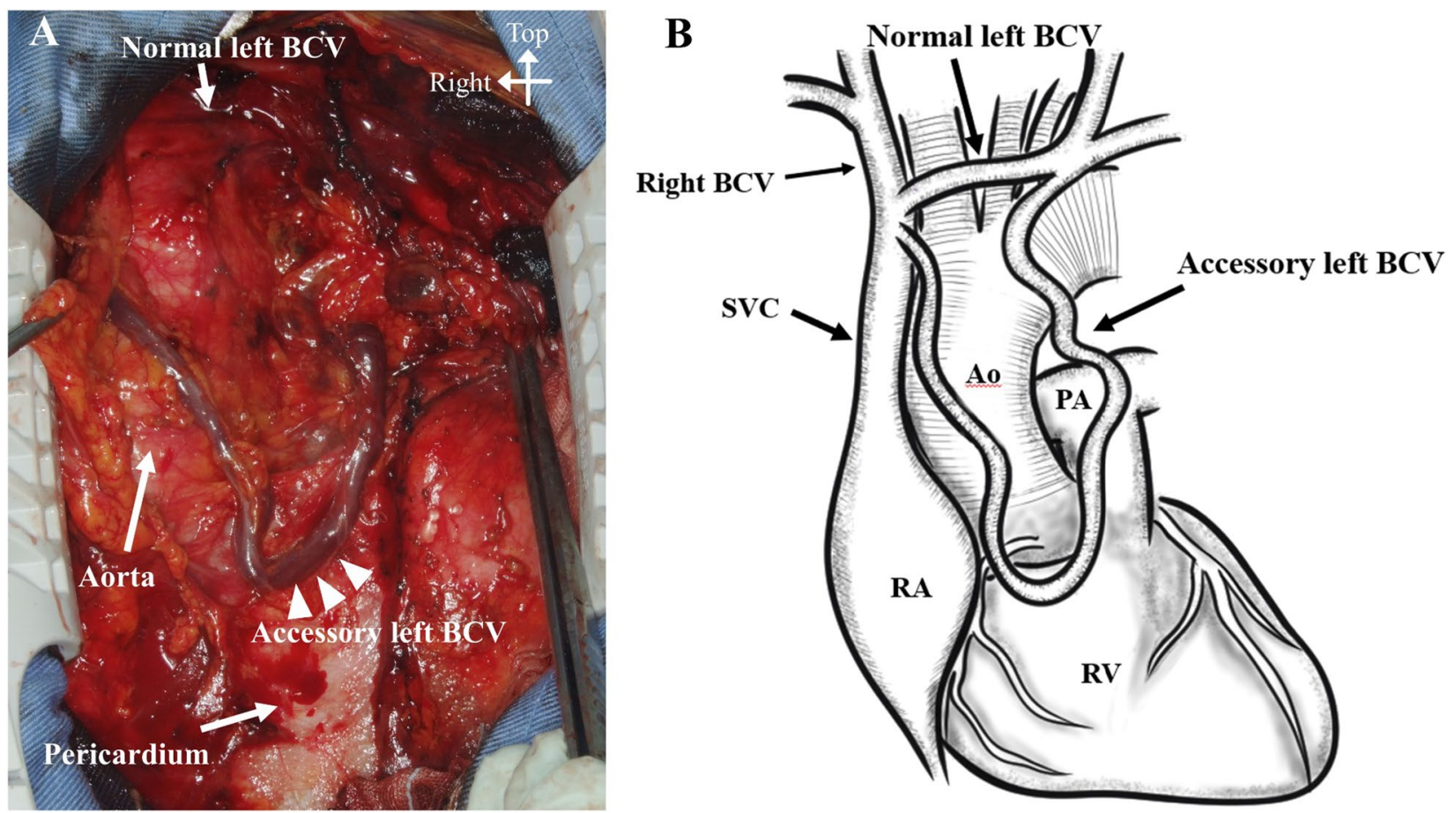

Fig. 2 A The intraoperative image of the accessory left brachiocephalic vein passing across the ascending aorta and heart in front of the pericardium. B Schematic drawing of the double left brachiocephalic vein with a preaortic course. Ao, ascending aorta; BCV, brachiocephalic vein; PA, pulmonary artery; RA, right atrium; RV, right ventricle; SVC, superior vena cava 

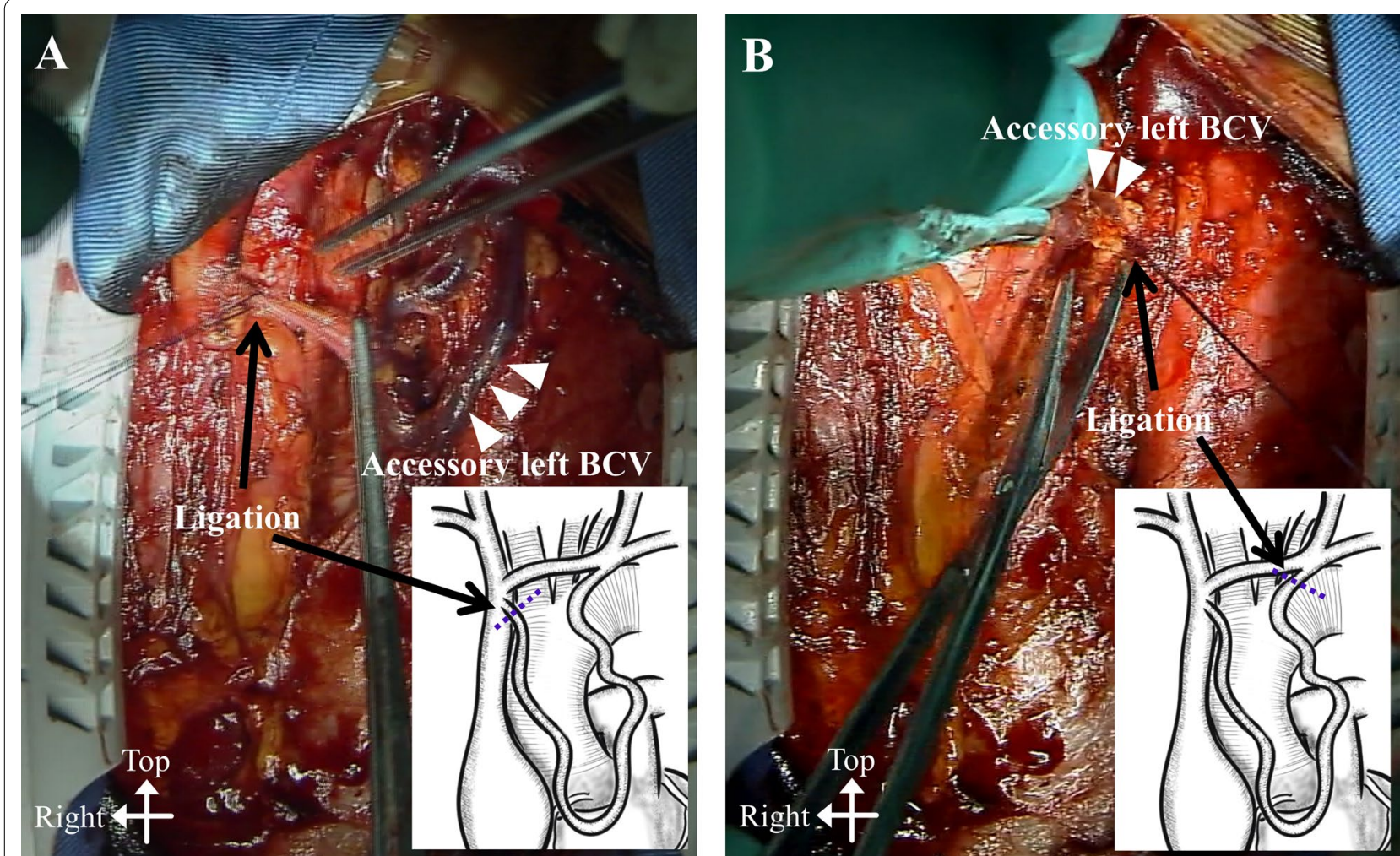

Fig. 3 Intraoperative images showing the ligation of the accessory left brachiocephalic vein close to its junction with the $\mathbf{A}$ superior vena cava and B normal left brachiocephalic vein. BCV, brachiocephalic vein

may be some technical difficulties and a potential risk of venous injury due to an undiagnosed accessory left $\operatorname{BCV}[1,2,5]$.

In our present case, the accessory left $\mathrm{BCV}$ was diagnosed preoperatively. Therefore, we recognized the abnormal preaortic pathway of this accessory left $\mathrm{BCV}$ and patency of the normal left $\mathrm{BCV}$. This enabled us to safely ligate the accessory left $\mathrm{BCV}$ prior to the intended cardiac surgical procedures. However, if the normal left BCV is hypoplastic, severely stenotic [5], or occluded [6], preservation of the accessory left $\mathrm{BCV}$ throughout the procedure, or transection followed by reconstruction, should be mandatory to avoid upper body congestion. In patients with an undiagnosed double left $\mathrm{BCV}$, there is the risk of unexpected intraoperative bleeding due to injury of the accessory left $\mathrm{BCV}$, particularly if it has a preaortic course.

For the establishment of cardiopulmonary bypass, there are some technical issues in patients with double left BCVs. There is a potential risk of inadequate venous drainage due to the obstruction of the aberrant $\mathrm{BCV}$ opening at the superior vena cava by the venous cannula itself [4]. Differentiating between the accessory left BCV and persistent left superior vena cava is also important to determine the necessity of additional venous cannulas for use in a cardiopulmonary bypass.

Preoperative venous evaluation is important in patients undergoing cardiac surgical procedures $[1,4]$. Contrastenhanced multidetector $\mathrm{CT}$ images are useful for the precise, preoperative diagnosis of left $\mathrm{BCV}$ anomalies [4]. The possibility of misidentifying an accessory left $\mathrm{BCV}$ as a mediastinal lymph node on unenhanced $\mathrm{CT}$ has been suggested as a potential risk $[4,7]$.

Although the double left $\mathrm{BCV}$ is rare, cardiovascular surgeons should be aware of this venous anomaly to avoid several intraoperative complications.

\section{Abbreviations}

BCV: Brachiocephalic vein; CT: Computed tomography,

\section{Acknowledgements}

We thank Editage (www.editage.jp) for English language editing.

\section{Authors' contributions}

TU and YK performed the surgery. KK and TU were major contributors to the writing of the manuscript. All authors read and approved the final manuscript.

\section{Funding}

The authors declare that this work was not supported by any grants or funding support. 


\section{Availability of data and materials}

The data are not available for public access due to patient privacy concerns but are available from the corresponding author upon reasonable request.

\section{Declarations}

Ethics approval and consent to participate

Not applicable.

\section{Consent for publication}

Informed consent to publish was obtained from the patient presented in this article.

\section{Competing interests}

The authors declare that they have no competing interests.

Received: 17 August 2020 Accepted: 23 August 2021

Published online: 28 August 2021

\section{References}

1. Yamamuro H, Ichikawa T, Hashimoto J, Ono S, Nagata Y, Kawada S, et al. Congenital anomalies of the left brachiocephalic vein detected in adults on computed tomography. Jpn J Radiol. 2017;35:597-605.
2. Hwang GH, Lee KH, Cho SG, Jeon YS, Kim YJ, Lee HY, et al. Double left brachiocephalic vein with a preaortic course: a rare finding. Surg Radiol Anat. 2018:40:357-60.

3. Subirana MT, de Leval M, Somerville J. Double left innominate vein: an unusual cross-sectional echocardiographic appearance. Int J Cardiol. 1986;12:263-5

4. Chen SJ, Liu KL, Chen HY, Chiu IS, Lee WJ, Wu MH, et al. Anomalous brachiocephalic vein: CT, embryology, and clinical implications. AJR Am J Roentgenol. 2005;184:1235-40.

5. Kawamura I, Hojo R, Fukamizu S. A case of pacemaker implantation in the patient with duplication of the left innominate vein: a case report. Springerplus. 2016:5:515.

6. Nagashima M, Shikata F, Okamura T, Yamamoto E, Higaki T, Kawamura M, et al. Anomalous subaortic left brachiocephalic vein in surgical cases and literature review. Clin Anat. 2010;23:950-5.

7. Topcuoglu OM, Atceken Z, Ariyurek OM. Circumaortic doubled left brachiocephalic vein: a rare confusing variation. Surg Radiol Anat. 2015;37:315-8

\section{Publisher's Note}

Springer Nature remains neutral with regard to jurisdictional claims in published maps and institutional affiliations.
Ready to submit your research? Choose BMC and benefit from

- fast, convenient online submission

- thorough peer review by experienced researchers in your field

- rapid publication on acceptance

- support for research data, including large and complex data types

- gold Open Access which fosters wider collaboration and increased citations

- maximum visibility for your research: over 100M website views per year

At BMC, research is always in progress.

Learn more biomedcentral.com/submissions 